\title{
The Structure of the Pyoverdin Isolated from Various Pseudomonas syringae Pathovars $^{\S}$
}

Markus Jülich ${ }^{\mathrm{a}}$, Kambiz Taraz ${ }^{\mathrm{a}}$, Herbert Budzikiewicz ${ }^{\mathrm{a}, *}$, Valerie Geoffroy, JeanMarie Meyer ${ }^{\mathrm{b}}$ and Louis Gardan ${ }^{\mathrm{c}}$

a Institut für Organische Chemie der Universität zu Köln, Greinstr. 4, 50939 Köln, Germany. Fax +49-221-470-5057. E-mail: aco88@uni-koeln.de

b Laboratoire de Microbiologie, UPRES-A $7010 \mathrm{du} C N R S$, Université Louis Pasteur, 28 rue Goethe, 67083 Strasbourg, France.

c UMR de Pathologie Végétale, INRA-INH-Université, 42 rue G. Morel, 49071 Beaucouzé, France

*Author for correspondence and reprint requests

Z. Naturforsch. 56c, 687-694 (2001); received April 10/May 10, 2001

Pseudomonas syringae, Pyoverdin, Siderophore

From seven different pathovars of Pseudomonas syringae representing various genetic subgroups, and one strain of Pseudomonas viridiflava the same pyoverdin siderophore (1) was isolated, probably identical with the pyoverdin whose amino acid composition (but not their sequence) had been reported before. 1 is the first pyoverdin where two of the ligands for $\mathrm{Fe}^{3+}$ are $\beta$-hydroxy Asp units. Its remarkably high complexing constant for $\mathrm{Fe}^{3+}$ at $\mathrm{pH} 5$ as compared with other pyoverdins offers a definite advantage in plant infection. The structure elucidation of $\mathbf{1}$ will be described and the taxonomical implications regarding pyoverdins with different structures ascribed previously to $P$. syringae strains will be discussed.

§ Part CV of the series "Bacterial constituents". For part CIV see Hohlneicher et al. (2001).

Abbreviations: Common amino acids, 3-letter code; aThr, alloThr; OHAsp, $\beta$-hydroxy-Asp; AcOHOrn, $\mathrm{N}^{5}$-acetyl-N ${ }^{5}$-hydroxy-Orn; cOHOrn, cyclo- $\mathrm{N}^{5}$-hydroxy-Orn (3-amino-1-hydroxy-piperidone-2); TAP, N/O-trifluoroacetyl (amino acid) isopropyl ester; Chr, pyoverdin chromophore; Suc, succinic acid side chain; Suca, succinamide side chain; ESI, electrospray ionization; FAB, fast atom bombardment; $\mathrm{CA}$, collision activation; $\mathrm{u}$, mass units based on the ${ }^{12} \mathrm{C}$ scale; COSY, correlated spectroscopy; DEPT, distortionless enhancement by polarization transfer; HMBC, heteronuclear multiple bond correlation; HMQC, heteronuclear multiple quantum coherence; NOE, nuclear Overhauser effect; ROESY, rotating frame nuclear Overhauser and exchange spectroscopy; TOCSY, total correlation spectroscopy; WATERGATE, water suppression by gradient-tailored excitation; DSS, 2,2-dimethyl-2-silapentane-5-sulfonate; TMS, tetramethylsilane; pv, pathovar; ATCC, American Type Culture Collection; CFBP, Collection Française de bactéries phytopathogènes; LMG, Laboratorium voor Microbiologie van Ghent, Belgian Coordinated Collection of Microorganisms.

\section{Introduction}

Several Pseudomonas spp. are known as dangerous plant pathogens, e.g., P. marginalis for the bacterial soft rot of many plants (Bradbury, 1986), $P$. tolaasii infecting mushroom cultures (Munsch et al., 2000; Uría Fernández et al., 2001), and P. syringae whose so-called pathovars (abbreviated pv.) infect a large variety of plant species. For this purpose $P$. syringae can rely on a large supply of secondary metabolites, small cytotoxic compounds as, e.g., coronatine and congeners (Mitchel, 1985) as well as a variety of lipopeptides (e.g., syringomycin, Fukuchi et al., 1992, or pseudomycins, Ballio et al., 1994) which can facilitate the penetration of cell walls. It is astonishing that relatively little is known about its siderophores necessary for an adequate supply of iron (see below).

P. syringae belongs to the $\gamma$ branch of the Proteobacteriaceae (Kersters et al., 1996) and is a member of the phytopathogenic group (characterized by the absence of oxidase and Arg hydrolase) of the fluorescent Pseudomonas spp. in the rRNA homology group I of the Pseudomonadaceae (Palleroni, 1984), the typical siderophores of which are the pyoverdins (Budzikiewicz, 1997). The pyoverdin produced by the type species $P$. syringae pv. syringae ATCC 19310 (1, Fig. 1), whose structure elucidation will be described below, shows several peculiarities as compared with the 


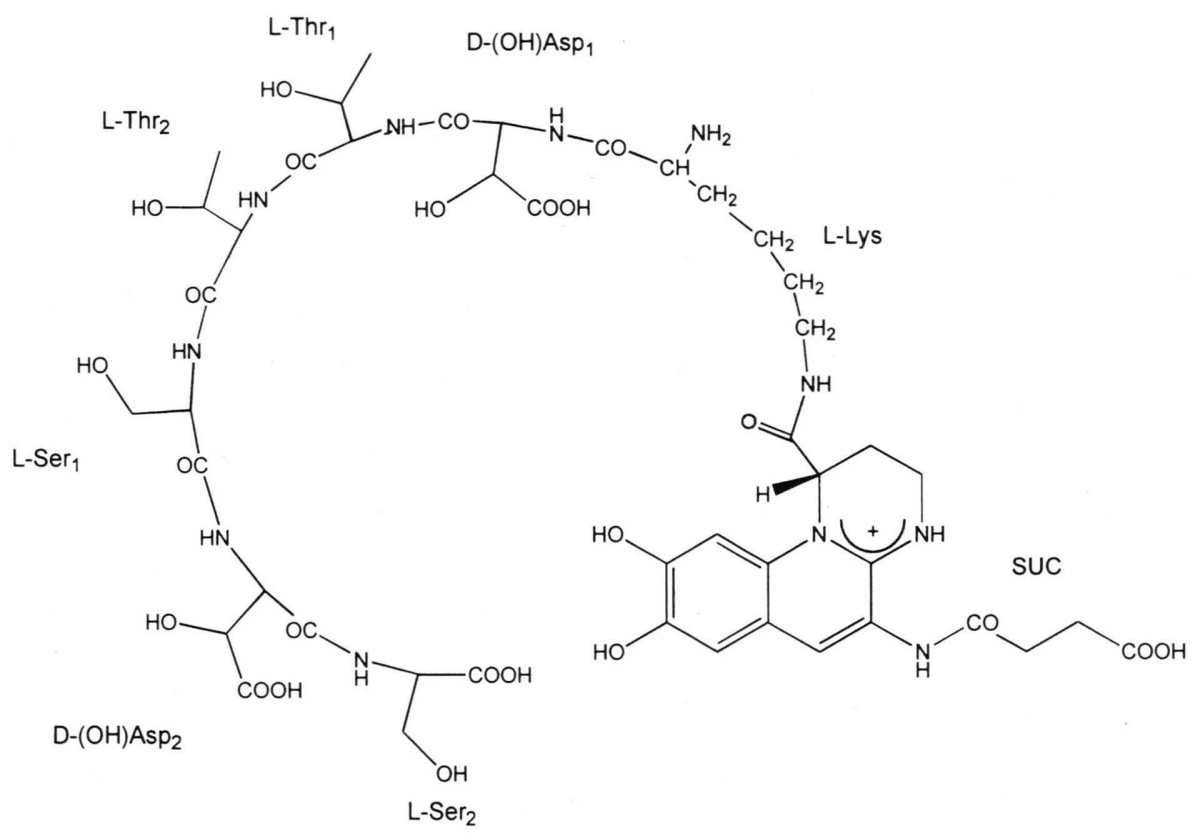

Fig. 1. Structure 1a of the pyoverdins from Pseudomonas syringae strains; $\mathbf{1 b}$ with $\mathrm{CONH}_{2}(\mathrm{Suca})$ instead of $\mathrm{COOH}$ (Suc) in the side chain.

pyoverdins isolated from saprophytic Pseudomonas spp. (Kilz et al.,1999; Fuchs and Budzikiewicz, 2001). 1 seems to be the prevalent (if not the sole) pyoverdin produced by the many genetically differing pathovars of $P$. syringae in contrast to the large variety of pyoverdins encountered with the saprophytic fluorescent Pseudomonas spp.

\section{Materials and Methods}

\section{Instruments, techniques and chemicals}

Mass spectrometry: FAB Finnigan-MAT HSQ30 (matrix thioglycerol/dithiodiethanol), ESI Finnigan-MAT 900 ST (solvent $\mathrm{CH}_{3} \mathrm{OH} / \mathrm{H}_{2} \mathrm{O} / 1 \%$ $\mathrm{CH}_{3} \mathrm{COOH}$ in $\mathrm{H}_{2} \mathrm{O}$ 50:50:1 v/v); GC/MS Incos 500 (both Finnigan-MAT, Bremen). Collision activation (CA) was effected either in the ion trap or in the octapole region before the ion trap.

NMR: DRX 300 and 500 (Bruker, Karlsruhe). Chemical shifts relative to TMS with the internal standard DSS; $\delta$ (TMS) $=\delta($ DSS $)$ for ${ }^{1} \mathrm{H}$, $\delta(\mathrm{DSS})=-1.61 \mathrm{ppm}$ for ${ }^{13} \mathrm{C}$. Suppression of the $\mathrm{H}_{2} \mathrm{O}$ signal by the WATERGATE puls sequence. Samples ca. $10 \mathrm{mg}$ in $0.6 \mathrm{ml} \mathrm{H} \mathrm{H}_{2} \mathrm{O} / \mathrm{D}_{2} \mathrm{O}$ 9:1.

UV/Vis: Lambda 7 (Perkin-Elmer, Überlingen), $1 \mathrm{mg}$ in $10 \mathrm{ml}$ buffer solution $(0.12 \mathrm{~mm}$, phosphate buffer, pH 5.0 and 7.0) with the buffer solution as reference.

Chromatography: Low pressure chromatography columns XAD-4 (Serva, Heidelberg), Biogel P-2 (Bio-Rad, Richmond CA, USA), CM-Sephadex C-25 and DEAE Sephadex A-25 and QAE Sephadex A-25 (Pharmacia, Uppsala, S), Sep-Pak $\mathrm{RP}_{18}$ cartridges (Waters, Milford MA, USA); HPLC Nucleosil-100 $\mathrm{C}_{18}(5 \mu \mathrm{m})$ and Eurosphere$100 \mathrm{C}-18(7 \mu \mathrm{m})$; GC/MS: Chirasil-L-Val (Chrompack, Frankfurt). DC Polygram Polyamid-6UV 254 (Macherey-Nagel, Düren).

Isoelectrofocussing (IEF): For the analysis of pyoverdin isoforms see Meyer et al. (1998). The bacteria were grown under iron starvation in a CAA medium (see below). ${ }^{59} \mathrm{Fe}$-uptake studies: For details see Geoffroy et al. (2001). The values given in Fig. 2 were measured after 20 min of incubation and corrected for blank values obtained in assays without bacteria.

Chemicals: Water was desalted and distilled twice in a quartz apparatus. Organic solvents were distilled over a column. Reagents were of p.a. quality. CAA-medium: $5 \mathrm{~g}$ low-iron casein hydrolysate (Bacto Casamino Acids, Difco, Augsburg) in $800 \mathrm{ml}, \quad 0.5 \mathrm{~g} \quad \mathrm{MgSO}_{4} \cdot 7 \mathrm{H}_{2} \mathrm{O}$ in $100 \mathrm{ml}, \quad 0.7 \mathrm{~g}$ 
$\mathrm{KH}_{2} \mathrm{PO}_{4}+1.3 \mathrm{~g} \mathrm{~K}_{2} \mathrm{HPO}_{4}$ in $100 \mathrm{ml} \mathrm{H}_{2} \mathrm{O}$. The solutions were sterilized at $130{ }^{\circ} \mathrm{C}$ for $20 \mathrm{~min}$ and poured together while still hot.

\section{Production and isolation of $\mathbf{1 a}$}

Pseudomonas syringae can be grown in so-called minimal media containing only glucose, gluconate or succinate as carbon source. However, the highest pyoverdin production (ca. three times more than in minimal media was achieved after ca. 72 hrs of cultivation in a CAA medium containing ca. $1 \mu \mathrm{m} / \mathrm{F} \mathrm{Fe}^{3+}$. For the work-up of the culture medium by chromatography on a XAD-4 column see Georgias et al. (1999). The eluate was brought to dryness i.v. at $30^{\circ} \mathrm{C}$, redissolved in $0.02 \mathrm{~m}$ pyridinium acetate buffer ( $\mathrm{pH}$ 5.0) and chromatographed on biogel P-2 with the same buffer. The same procedure was repeated by chromatography on CMSephadex C-25 (solvent $\mathrm{H}_{2} \mathrm{O}$ ), on DEAE Sephadex A-25 (solvent 0.02 m pyridinium acetate buffer, pH 5.0) and on QAE sephadex A-25 (same solvent). Final purification was effected by preparative HPLC on a RP-18 column with a $0.1 \mathrm{M}$ $\mathrm{CH}_{3} \mathrm{COOH}$ in $\mathrm{H}_{2} \mathrm{O} / \mathrm{CH}_{3} \mathrm{OH}$ gradient (5 to $30 \%$ $\mathrm{CH}_{3} \mathrm{OH}$ ) and checked by analytical HPLC. Detection for all chromatographic steps at $405 \mathrm{~nm}$.

For decomplexation 1a was dissolved in $1 \%$ aqueous citric acid and extracted several times with a $5 \%$ solution of 8-hydroxyquinoline in $\mathrm{CHCl}_{3}$ and than with pure $\mathrm{CHCl}_{3}$. The aqueous phase was chromatographed on Biogel P-2 (solvent $0.1 \mathrm{M}$ acetic acid) and brought to dryness i.v. at $30{ }^{\circ} \mathrm{C}$, redissolved in $\mathrm{H}_{2} \mathrm{O}$ and again brought to dryness; purity control by RP-HPLC. For qualitative and quantitative analysis of the amino acids and the determination of their configuration by GC/MS of their TAP derivatives on a chiral column and for dansyl derivatisation see Briskot et al. (1986) and Mohn et al. (1990).

\section{Results}

\section{Siderotyping behavior of the P. syringae strains}

The pyoverdin isoforms (differing in the side chain attached to the chromophore) produced during growth of $P$. syringae pv. syringae ATCC 19310 in a CAA medium were differentiated as two fluorescent bands with $\mathrm{pI}$ values of 4.5 and
3.9, respectively, when subjected to isoelectrofocusing on ampholine-containing polyacrylamide gel with a 3 to $10 \mathrm{pH}$ gradient. A strictly identical pyoverdin-IEF pattern was observed for the other strains analyzed, namely $P$. syringae pv. aptata CFBP 1617, P. syringae pv. pisi CFBP 2105, P. syringae pv. atrofaciens CFBP 2213, P. syringae pv. tabaci CFBP 2106, P. syringae pv. passiflorae CFBP 2346, P. syringae pv. oryzae CFBP 3228 and $P$. viridiflava CFBP 2107, a strain closely related to the $P$. syringae species.

All these strains were then analyzed for their pyoverdin-mediated iron uptake capacity towards their respective pyoverdins and also towards the pyoverdin of the type strain $P$. syringae pv. syringae ATCC 19310. As shown in Fig. 2, each strain was able to use the pyoverdin of $P$. syringae pv. syringae ATCC 19310 as well as its own one with the same efficiency. Moreover, P. syringae pv. syringae ATCC 19310 was tested versus a collection of 34 pyoverdins of different bacterial origin (see Weber et al., 2000 for a listing of the pyoverdin collection and Kilz et al., 1999, for their structures) and revealed a strict specificity of recognition towards its own pyoverdin; none of the 34 foreign pyoverdins were able to mediate iron incorporation in the P. syringae strain (Geoffroy et al., 2001). Thus, it could be expected from the siderotyping and the uptake data that the set of $P$. syringae strains and the $P$. viridiflava strain produce the same novel pyoverdin.

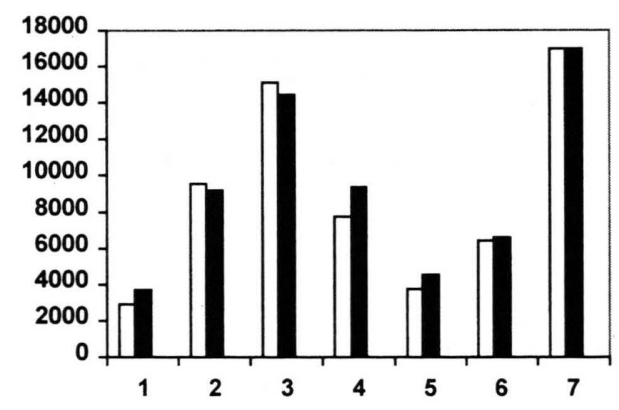

Fig. 2. Iron uptake (ordinate $\mathrm{cpm}$ ) by $P$. syringae pv. aptata (1), atrofaciens (2), tabaci (3); orycae (4), passiflorae (5), pisi (6) and P. viridiflava CFBP 2107 as mediated by the respective pyoverdins (white bars) and by the pyoverdin of $P$. syringae pv. syringae ATCC 19310 (black bars). 
Characterization of 1a from Pseudomonas syringae pv. syringae ATCC 19310

1a gives the characteristic UV/Vis spectrum of pyoverdins (Budzikiewicz, 1997), viz. $404 \mathrm{~nm}$ at pH 7.0 and a split band 368 and $373 \mathrm{~nm}$ at $\mathrm{pH} 3.0$; its $\mathrm{Fe}^{3+}$ complex shows the broad charge transfer bands at ca. 470 and $560 \mathrm{~nm}$. The molecular mass of $\mathbf{1 a}$ as determined by FAB-MS amounts to 1140 u. Amino acid analysis after total hydrolysis showed the presence of 2 D-OHAsp, L-Lys, 2 LSer and 2 L-Thr; in addition succinic acid di-isopropyl ester was detected. Total hydrolysis after dansylation yielded $\alpha$-dansyl Lys as could be shown by DC-chromatographic analysis in comparison with authentic $\alpha$ - and $\varepsilon$-dansyl Lys. Lys is, therefore, incorporated into the pyoverdin peptide chain by its $\varepsilon$-amino group (cf. below the NMR discussion). The absolute configuration of $\mathrm{C}-1$ of the chromophore was found to be $S$ from the CDspectrum of the 4-hydroxy chromophore obtained by hydrolysis (Michels et al., 1991). The $\mathrm{Fe}^{3+}$ complexing constants of 1a were determined via the equilibrium with the EDTA complex (Mohn et al., 1990). They were found to be $1.61 \cdot 10^{25}$ at $\mathrm{pH} 7.0$ and $6.03 \cdot 10^{21}$ at $\mathrm{pH} 5.0$. While the $\mathrm{pH} 7.0$ value agrees with the average of those determined for a series of pyoverdins (Budzikiewicz, 1997), the one at $\mathrm{pH} 5.0$ is by ca. two orders of magnitude higher than the average. The less facile protonation of the two OHAsp units as compared with hydroxamic acids could be the reason.
Further information regarding the structural elements contained in 1a can be gained from NMR data: Basis is the unambiguous identification of all ${ }^{1} \mathrm{H}$ - and ${ }^{13} \mathrm{C}$-signals by a combination of homoand heteronuclear one- and two-dimensional experiments: H, H-COSY allows to detect the ${ }^{3} \mathrm{~J}-$, TOCSY higher $\mathrm{H}, \mathrm{H}$-couplings. HMQC identifies ${ }^{1} \mathrm{~J}-\mathrm{C}, \mathrm{H}, \mathrm{HMBC}{ }^{2} \mathrm{~J}$ - and ${ }^{3} \mathrm{~J}$-coupling and allows thus to identify also quaternary C-atoms. HMBC indicates the number of $\mathrm{H}$-atoms bound to a carbon. Sequence information is obtained by ROESY which correlates spatially close protons and by HMBC correlating carbonyl and amide signals of neighboring amino acids.

The ${ }^{1} \mathrm{H}$ - and ${ }^{13} \mathrm{C}$-data are collected in Tables I and II. They correspond to those observed with other pyoverdins (Budzikiewicz, 1997). The following ones deserve a comment: The shift values of the $\beta-\mathrm{H}$ atoms of the Ser and aThr units indicate that the hydroxyl groups are not esterified, otherwise they would be observed about $0.5-$ $1.0 \mathrm{ppm}$ downfield (Budzikiewicz, 1997). The dansylation experiment had shown that Lys has a free $\alpha$-amino group and is, therefore, bound amidically by its $\varepsilon$-amino group to the carboxyl group of the chromophore. The signals of the Lys chain can be identified in the TOCSY and in the COSY spectrum, that of the $\varepsilon-\mathrm{NH}$ shows correlations with the $\delta$ - and the $\varepsilon-\mathrm{CH}_{2}$ groups. The low shift value of the $\varepsilon-\mathrm{NH}$ indicates a linkage to the chromophore carboxyl group. Sequence relevant

Table I. ${ }^{1} \mathrm{H}-\mathrm{NMR}$ data of $\mathbf{1 a}\left(\mathrm{H}_{2} \mathrm{O} / \mathrm{D}_{2} \mathrm{O} 9: 1, \mathrm{pH} 4.5,25^{\circ} \mathrm{C}\right)$

\begin{tabular}{lllllllll}
\hline Chr & 1 & 2 & 3 & $4-\mathrm{NH}^{+}$ & $5-\mathrm{NH}$ & 6 & 7 & 10 \\
\hline & 5.60 & 2.43 & 3.38 & 8.70 & 9.95 & 7.91 & 7.14 & 7.05 \\
\hline
\end{tabular}

\begin{tabular}{|c|c|c|c|c|c|c|c|}
\hline $\begin{array}{l}\text { peptide } \\
\text { chain }\end{array}$ & $\mathrm{NH}$ & $\alpha$ & B & $\gamma$ & $\delta$ & $\varepsilon$ & $\mathrm{NH}_{2}$ \\
\hline Lys & 9.08 & 4.13 & 1.88 & 1.31 & 1.57 & 3.32 & a \\
\hline OHAsp ${ }^{1}$ & 8.68 & 4.99 & 4.61 & & & & \\
\hline $\mathrm{Thr}^{1}$ & 8.30 & 4.56 & 4.39 & 1.22 & & & \\
\hline $\mathrm{Thr}^{2}$ & 8.26 & 4.45 & 4.30 & 1.22 & & & \\
\hline Ser $^{1}$ & 8.45 & 4.55 & 3.86 & & & & \\
\hline $\mathrm{OHAsp}^{2}$ & 8.38 & 4.95 & 4.69 & & & & \\
\hline $\mathrm{Ser}^{2}$ & 8.09 & 4.47 & 3.90 & & & & \\
\hline Suc & $2^{\prime}$ & $3^{\prime}$ & & & & & \\
\hline
\end{tabular}


Table II. ${ }^{13} \mathrm{C}-\mathrm{NMR}$ data of $\mathbf{1 a}$ (conditions as for Table I)

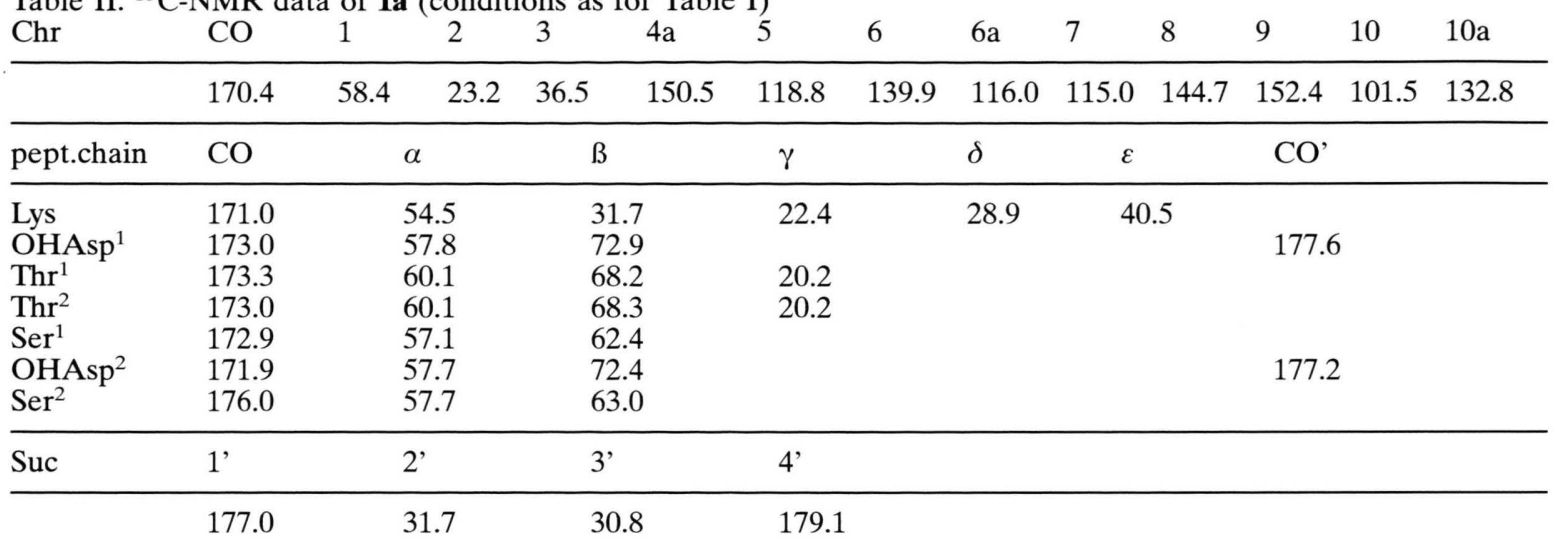

ROESY and HMBC cross peaks are indicated in Fig. 3.

The structure deduced from NMR data is confirmed by mass spectrometric fragmentation by CA (Fuchs and Budzikiewicz, 2001). The most important fragment ions of the peptide chain upon $\mathrm{CA}$ of $[\mathrm{M}+\mathrm{H}]^{+}$or of $[\mathrm{M}+2 \mathrm{H}]^{2+}$ are the N-terminal so-called B-ions (R'NH-CHR-CO ${ }^{+}$) (Roepstorff and Fohlman, 1984). The whole B-series accompanied by $\left[\mathrm{B}-\mathrm{H}_{2} \mathrm{O}\right]^{+}$-ions can be observed. Several C-terminal $\mathrm{Y}$ “-ions $\left(\mathrm{NH}_{3}{ }^{+} \mathrm{CHRCOR}\right.$ ") complete the pattern (Table III). Direct mass spectrometric analysis of the XAD extract shows the presence mainly of $\mathbf{1 b}$ with a succinamide (Suca) side chain in agreement with the earlier observation that the succinic acid (Suc) side chain is formed by hydrolysis in the culture medium (Schäfer et al., 1991) and during work-up. Due to the presence of Suca instead of Suc the masses of the B-ions are $1 \mathrm{u}$ lower than those given in Table III for 1a.

In the same way 1a was isolated from Pseudomonas syringae pv. atrofaciens CFBP 2213 and characterized by degradation, NMR and MS as described above. The XAD extracts obtained from P. syringae pv. tabaci CFBP 2106, pv. passiflorae CFBP 2346, pv. oryzae CFBP 3228, pv. aptata CFBP 1617, pv. pisi CFBP 2105 and P. viridiflava CFBP 2107 were subjected directly to mass spec-

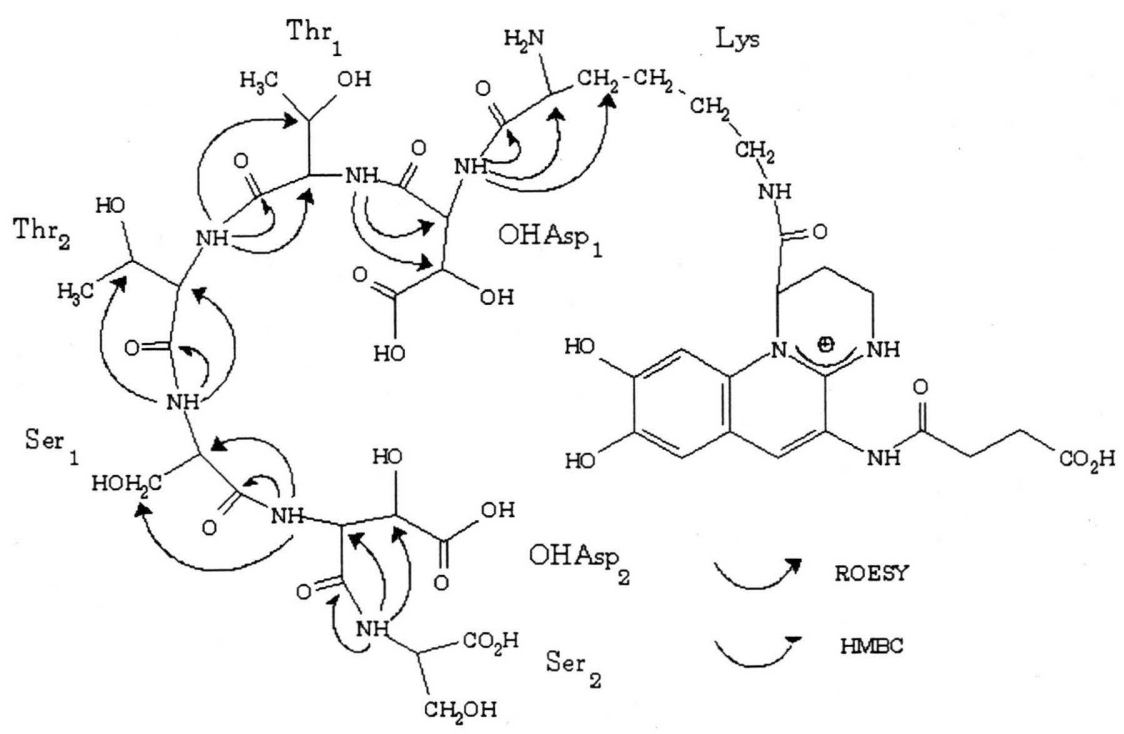

Fig. 3. Sequence relevant cross peaks for 1a derived from ROESY (full arrows) and HMBC (half arrows) experiments. 
Table III. Observed sequence specific fragment ions of 1a after collision activation in the ion trap.

\begin{tabular}{lllll} 
Fragment & $\mathrm{n}$ & Ion B & Ion $\mathrm{Y}^{*}$ & $\mathrm{n}$ \\
\hline Suc-Chr & 0 & $358^{\mathrm{a}}$ & & \\
$\varepsilon$-Lys & 1 & 486 & & 7 \\
OHAsp & 2 & 617 & & 6 \\
aThr & 3 & 718 & & 5 \\
aThr & 4 & 819 & 425 & 4 \\
Ser & 3 & 906 & 324 & 5 \\
OHAsp & 2 & 1037 & 237 & 2 \\
Ser & 7 & & & 1 \\
\hline
\end{tabular}

${ }^{\text {a }}$ Detected after activation in the octapole region

trometric analysis. Fragmentation induced by CA proved the presence of same amino acid sequence in every case.

\section{Discussion}

The pyoverdin 1 shows some peculiarities. It belongs to the smallest representatives with only seven amino acids in the peptide chain (so far six amino acids is the minimal number encountered) and it shows uncommonly little variability in the $\mathrm{D} / \mathrm{L}$-pattern of the amino acids. Among the over 50 pyoverdins where complete or fairly complete structures were established it is only the third example with an $\varepsilon$-Lys link of the peptide chain to the chromophore (cf. Teintze et al., 1981; Leong et al., 1991). More important, it is the first example where the two ligand sites in the peptide chain are both OHAsp. Their lower pKa as compared with hydroxamic acids found as complexing sites in other pyoverdins may be responsible for the unexpectedly high complexing constant at pH 5.0 (ca. two orders of magnitude higher than observed for other pyoverdins) which could give $P$. syringae a selectional advantage in its habitat.

The 56 pathovars of $P$. syringae and related species were studied by DNA-DNA hybridization and divided in eight genomic species. Genomospecies 1 (syringae), 2 (savastanoi), 3 (tomato) and 4 (porri) clustered 49 of the 56 pathovars and related species (Gardan et al., 1999). As it was shown above, P. syringae pv. syringae ATCC 19310, the type species, and pv. atrofaciens CFBP 2213 produce the same pyoverdin $\mathbf{1}$. From six other pathovars belonging to different subclusters according to the above classification, viz. $P$. syringae pv. tabaci CFBP 2106, pv. passiflorae CFBP 2346, pv. oryzae CFBP 3228 , pv. aptata CFBP 1617 , pv. pisi
CFBP 2105 and P. viridiflava CFBP 2107 their pyoverdins were isolated. They gave the same MS fragmentation pattern after CA as 1a (see above), the same IEF pattern and uptake of the ferri-pyoverdin produced by the type strain with the same rate as their own ones. This indicates identical structures. Bultreys and Gheysen (2000) had analyzed the amino acid composition of the pyoverdins isolated from $P$. syringae pv. syringae, pv. aptata, pv. morsprunorum, pv. tomato and from $P$. viridiflava LMG 2352. It is identical with that of 1. The same amino acid composition had also been found by Cody and Gross (1987) for the pyoverdin they had isolated from a $P$ syringae pv. syringae strain. Although both groups did not determine the stereochemistry and the sequence of the amino acids, the amino acid composition is so unique (see above) that it is safe to assume, that in all cases identical pyoverdins were obtained. A more detailled discussion of the microbiological and classificational aspects involving all the $P$. syringae pathovars and other related species will be published elsewhere (Geoffroy et al., 2001).

The strains investigated by us and by the Belgian group (Bultreys and Gheysen, 2000) were selected to cover a wide variety of $P$. syringae strains belonging to the four major genomospecies. They apparently all produce the same pyoverdin $\mathbf{1}$. It is therefore astonishing that in the literature three other structures were reported for pyoverdins from supposedly $P$. syringae strains:

(1) Torres et al. (1986) had isolated from a not further classified $P$. syringae strain a pyoverdin for which they reported the amino acid composition 3 Ser, 3 Thr, Lys and OHOrn. Probably 2 OHOrn are present to provide two binding sites in the peptide chain (due to partial decomposition during hydrolysis the Orn values are generally too low), but when adding up the masses of the components one reaches a molecular mass much higher than the one determined by the authors from their elemental analysis. Provided the calculated molecular mass is correct within reasonable limits, the number of Ser and Thr must be too high.

(2) For the pyoverdin of P. aptata 4a the structure Suca-Chr-D-Ala-L-Lys-L-Thr-D-Ser-L-AcOHOrn-L-cOHOrn was established (Budzikiewicz et al., 1992). Originally, the strain was classified as $P$. aptata because it caused lesions on sugar beet leaves. However, a phenotypic analysis of the 
strain revealed that it was oxidase positive and that it did not respond positively to a phytopathogenicity test done on tobacco leaves, as the $P$. syringae strains do (Geoffroy et al., 2001). Therefore, it could be concluded that the so-called "P. aptata $4 \mathrm{a}$ " isolate has been misidentified and does not belong to the $P$. syringae group. Interestingly, the same amino acid sequence (the stereochemistry of the amino acids had not been determined) was found for the pyoverdin of $P$. fluorescens SB8-3, a saprophytic pseudomonad (Demange et al., 1986 and unpublished results from this laboratory).

(3) For the pyoverdin of $P$. aptata 3 b (identified in the same way as P. aptata 4 a as causing lesions on sugar beet leaves; its belonging to the P. syringae species remains therefore doubtful) the amino acid sequence L-Asp-[L-AcOHOrn-Dab]-Thr-DAla-Thr-Thr-Gln-L-cOHOrn (2 D-Thr, 1 L-aThr; the amino acid analysis had been effected with the accompanying ferribactin having a Glu side chain giving D- and L-Glu, but since the ferribactin Glu side chains have so far always been found to be $\mathrm{L}$, Gln in the peptide chain should be D) was established (Tappe, 1991). [AcOHOrn-Dab] indicates the condensation product between Orn and Dab giving a tetrahydropyrimidine ring (Demange et al., 1990; Filsak et al., 1994).

These three structures have little in common and differ grossly from that of $\mathbf{1}$. A correct identification of the investigated strains may at least be questioned.
Ballio A., Bossa F., di Giorgio D., Ferranti P., Paci M., Pucci P., Scaloni A., Segre A. and Strobel G. A. (1994), Novel bioactive lipodepsipeptides from Pseudomonas syringae: the pseudomycins. FEBS Lett $\mathbf{3 5 5}$, 96-100.

Bradbury J. F. (1986), Pseudomonas Migula 1894. Guide to Pant Pathogenic Bacteria, International Mycobiological Institute, Egham UK; pp. 110-184.

Briskot G., Taraz K, Budzikiewicz H. (1986), Siderophore vom Pyoverdin-Typ aus Pseudomonas aeruginosa. Z. Naturforsch. 41c, 497-506.

Budzikiewicz H. (1997), Siderophores from fluorescent Pseudomonas. Studies in Natural Products Chemistry (Atta-ur-Rahman, ed.), Elsevier, Amsterdam; vol. 19, $793-835$.

Budzikiewicz H., Schröder H. and Taraz K. (1992), Zur Biogenese der Pseudomonas-Siderophore: Der Nachweis analoger Strukturen eines Pyoverdin-Desferriferribactin-Paares. Z. Naturforsch. 46c, 26-32.

Bultreys A. and Gheysen I. (2000), Production and comparison of peptide siderophores from strains of distantly related pathovars of Pseudomonas syringae and Pseudomonas viridiflava LMG 2352. Appl. Environ. Microbiol. 66, 325-331.

Cody Y. S. and Gross D. C. (1987), Characterization of pyoverdin $_{\mathrm{pss}}$, the fluorescent siderophore produced by Pseudomonas syringae pv. syringae. Appl. Environ. Microbiol. 53, 928-234.

Demange P., Wendenbaum S., Bateman A., Dell A., Meyer J.-M. and Abdallah M. A. (1986), Bacterial siderophores: Structure of pyoverdins and related compounds in Iron, Siderophores, and Plant Diseases (Swineburne, T. R., ed.), Plenum, New York, p. 131147.

Demange P., Bateman A., MacLeod J. K., Dell A. and Abdallah M. A. (1990), Bacterial siderophores: unusual 3,4,5,6-tetrahydropyrimidine-based amino acids in pyoverdins from Pseudomonas fluorescens. Tetrahedron Lett. 31, 7611-7614.
Filsak G., Taraz K. and Budzikiewicz H. (1994), Untersuchungen zur Struktur und Derivatisierung von Kondensationsprodukten der 2,4-Diaminobuttersäure mit anderen Aminosäuren. Z. Naturforsch. 49c, 18-25.

Fuchs R. and Budzikiewicz H. (2001), Structural studies of pyoverdins by mass spectrometry. Curr. Org. Chem., 5, 265-288.

Fukuchi N., Isogai A., Nakayama J., Takayama A., Yamashita Sh., Suyama K., Takemoto J. Y. and Suzuki A. (1992), Structure and stereochemistry of three phytotoxins, syringomycin, syringotoxin and syringostatin, produced by Pseudomonas syringae pv. syringae. J. Chem. Soc. Perkin Trans. 1149-1157.

Gardan L., Shafik H., Belouin S., Broch R., Grimont F. and Grimont P. A. D. (1999), DNA relatedness among pathovars of Pseudomonas syringae and decription of Pseudomonas tremae sp. nov. and Pseudomonas cannabina sp. nov. (ex Sutic and Dawsom 1959). Inter. J. Syst. Bacteriol. 49, 469-478.

Geoffroy V. A., Meyer J.-M., Gardan L., Jülich M., Taraz K. and Budzikiewicz H. (2001), Siderotyping reveals a unique pyoverdine system for iron uptake among Pseudomonas syringae pathovars and related species. Res. Microbiol. (submitted).

Georgias H., Taraz K., Budzikiewicz H., Geoffroy V. and Meyer J.-M. (1999), The structure of the pyoverdin from Pseudomonas fluorescens 1.3. Structural and biological relationships of pyoverdins from different strains. Z. Naturforsch. 54c, 301-308.

Hohlneicher, U., Schäfer, M., Fuchs, R. and Budzikiewicz, H. (2001), Ferribactins as the biosynthetic precursors of the Pseudomonas siderophores pyoverdins. Z. Naturforsch. 56c, 308-310.

Kersters K., Ludwig W., Vancanneyt M., De Vos P., Gillis M. and Schleifer K. H. (1996), Recent changes in the classification of the pseudomonads: an overview. Syst. Appl. Microbiol. 19, 465-477

Kilz S., Lenz Ch., Fuchs R. and Budzikiewicz H. (1999), A fast screening method for the identification of sid- 
erophores from fluorescent Pseudomonas spp. by liquid chromatography/electrospray mass spectrometry. J. Mass Spectrom. 34, 281-290.

Leong J., Bitter W., Koster M., Venturi V. and Weisbeek P. J. (1991), Molecular analysis of iron transport in plant growth-promoting Pseudomonas putida WCS358. Biol. Metals 4, 36-40.

Meyer J.-M., Stintzi A., Coulanges V., Shivaji S., Voss J. A., Taraz K. and Budzikiewicz H. (1998), Siderotyping of fluorescent pseudomonads: characterization of pyoverdines of Pseudomonas fluorescens and Pseudomonas putida strains from Antarctica. Microbiology 144, 3119-3126.

Michels J., Benoni H., Briskot G., Lex J., Schmickler H., Taraz K. and Budzikiewicz H. (1991), Isolierung und spektroskopische Charakterisierung des PyoverdinChromophors sowie seines 5-Hydroxy-Analogen. Z. Naturforsch. 46c, 993-1000.

Mitchel R. E. (1985), Norcoronatine and N-coronafacoyl-L-valine, phytotoxic analogues of coronatine produced by a strain of Pseudomonas syringae pv. glycinae. Phytochemistry 24, 1485-1487.

Mohn G., Taraz K. and Budzikiewicz H. (1990), New pyoverdin-type siderophores from Pseudomonas fluorescens. Z. Naturforsch. 45b, 1437-1450.

Munsch P., Geoffroy V., Alatossava T. and Meyer J-M. (2000), Application of siderotyping for characterization of Pseudomonas tolaasii and "Pseudomonas reactans" isolates associated with brown blotch disease of cultivated mushrooms. Applied Environ. Microbiol. 66, $4834-4841$.
Palleroni N. J. (1984), Pseudomonadaceae. Bergey's Manual of Systematic Bacteriology (Krieg N. R. and Holt J. G., eds), Williams and Wilkins, Baltimore; vol. 1, pp. $141-199$.

Roepstorff P. and Fohlman J. 1984. Proposal of a common nomenclature for sequence ions in mass spectra of peptides. Biomed. Mass Spectrom. 11, 601.

Schäfer H., Taraz K. and Budzikiewicz H. (1991), Zur Genese der amidisch an den Chromophor von Pyoverdinen gebundenen Dicarbonsäuren. Z. Naturforsch. 46c, 398- 406.

Tappe, R. (1991), Ferribactin 3b, ein Siderophor von Pseudomonas aptata 3b. Diplomarbeit, Universität zu Köln and unpublished results.

Teintze M., Hossain M. B., Barnes C. L., Leong J. and v. d. Helm D. (1981), Structure of ferric pseudobactin, a siderophore from a plant growth promoting Pseudomonas. Biochemistry 20, 6446-6457.

Torres L., Pérez-Ortín J. E., Tordera V. and Beltrán J. P. (1986), Isolation and characterization of an Fe(III)chelating compound produced by Pseudomonas syringae. Appl. Environ. Microbiol. 52, 157-160.

Uría Fernández D., Fuchs R., Taraz K., Budzikiewicz H., Munsch P. and Meyer J.-M. (2001), The structure of a pyoverdine produced by a Pseudomonas tolaasii-like isolate. BioMetals, 14, 81-84.

Weber M., Taraz K., Budzikiewicz H., Geoffroy V. and Meyer J.-M (2000). The structure of a pyoverdine from Pseudomonas sp. CFML 96-188 and its relation to other pyoverdines with a cyclic $\mathrm{C}$-terminus. BioMetals 13, 301-309. 